Рад примљен: 23. 2. 2020.

Рад прихваћен: 20. 4. 2020.

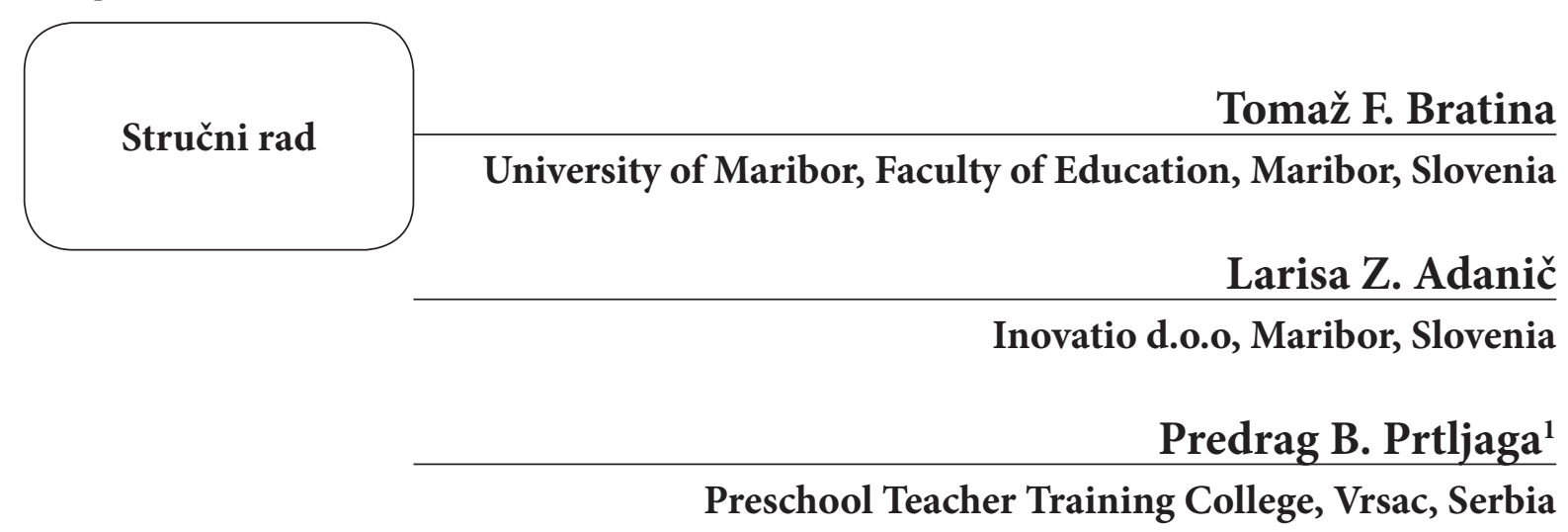

\title{
Teachers, Interactive Whiteboards and Learning Materials in Slovenia and Serbia
}

\begin{abstract}
Summary: The modern-day classrooms are equipped with interactive whiteboards driven by corresponding software. Using the advantages of the interactive whiteboards is often limited by the lack of knowledge about the software or lack of time to prepare learning materials. Some practical suggestions, examples, or ideas on how teachers should prepare the learning material suitable for interactive whiteboards may be very useful and encourage the usage by the teachers. Art education is an area where the majority of tools provided by the software can be in use to a great extent. The collections of interactive whiteboard learning materials were prepared to help teachers implement the interactive whiteboards in the teaching process. The selected topics in this paper point to the advantages of whiteboard learning materials, based on the responses of potential users (teachers) and brief descriptions of testing results showing opinions about effectiveness and suitability. The results, in brief, show that teachers and students assess the collection as a very helpful tool, which also promotes the implementation of interactive whiteboards into the learning process. Art teachers have confirmed the relative simplicity regarding the application or usage of the interactive whiteboard learning materials and expressed their willingness to teach with the collection throughout the teaching process. The results are encouraging, pointing to a trend toward using interactive whiteboard learning materials in everyday practice.
\end{abstract}

Keywords: interactive whiteboard, learning materials, art education, teaching process, learning material repository.

1 jpivan@hemo.net

Copyright (C) 2020 by the authors, licensee Teacher Education Faculty University of Belgrade, SERBIA.

This is an open access article distributed under the terms of the Creative Commons Attribution License (CC BY 4.0) (https://creativecommons.org/licenses/by/4.0/), which permits unrestricted use, distribution, and reproduction in any medium, provided the original paper is accurately cited. 


\section{Introduction}

The number of interactive whiteboards in the world has grown significantly over the last decade. An analysis of the equipment of elementary schools in Slovenia with interactive whiteboards has shown that there are more classrooms equipped with interactive whiteboards at the upper primary level than at the lower primary level (Bučar, 2011). We assume that school executives have decided to take this step because of the more complex content of the subjects taught at this stage. An analysis of the use of the interactive whiteboard by classroom teachers also shows that almost a half of the teachers often use the interactive whiteboard (Vukanac, 2014).

An analysis of the situation regarding the use of ICT in schools in Serbia shows that the equipment of schools with interactive whiteboards depends on the size of the school, the economic situation of the local community, participation in projects, and the role of employees. It is the impact of the size of the school and the economic situation of the local community that are the biggest obstacles to equipping (Džigurski et al., 2013). According to Ristić (2018), the use of ICT, as well as interactive whiteboards, is still dependent on the digital competencies and enthusiasm of individuals. She also points to the need to increase digital competences at all levels of education, especially at the university level. The situation regarding equipment with interactive whiteboards in the Republic of Serbia has been improving. However, a more frequent use is more prevalent in the field of science, especially in physics classes (Oprea, 2017).

Teachers at the lower primary level in Slovenia pay much more attention to motivational elements in teaching and see the possibility of ICT technology as an enhancement of the learning content. From our experience in teacher education, we find that most teachers are less familiar with the software, so self-education of teachers and participation in seminars is required. Seminars, however, are an excellent opportunity to exchange experienc- es and to present examples of interactive whiteboard software.

\section{Interactive Whiteboard}

The interactive board is a touch-sensitive device as a standalone computer or a touch-sensitive board connected to the computer and projector. Whiteboards may be attached to the wall or on mobile stands. The required drivers are usually installed on the computer, enabling the whiteboard to act as a Human Input Device like a mouse or a similar device. The computer's video output (VGA and HDMI) has a connection to a digital projector that projects an image onto the surface of an interactive whiteboard. When the interactive whiteboard is in connection to a computer and projector, a computer image is visible on the interactive surface. Most interactive boards have specialised software that offers many interactive tools and features (Collaboration Software \& Displays - SMART Technologies, 2018).

The software itself is a disadvantage because it depends on the manufacturer of the interactive whiteboard and is therefore incompatible with other products.

The software detects the point of contact with the panel sensors and interprets it appropriately. The interactive whiteboard needs periodical calibration to ensure touch accuracy. By touching the interactive surface, it is possible to perform the operations provided in the dedicated applications and control the hardware or the operating system.

Most interactive whiteboards allow two ways of using: computer interaction mode with touch (mouse equivalent) and digital pen writing (Digregorio and Sobel-Lojevski, 2010).

\section{Types of interactive whiteboards}

Interactive whiteboards vary from manufacturer to manufacturer in the number of simultaneous touches, the precision of the detected touch, 
the software, and the possibilities of use (Bhowmik, 2014). According to technology, there are five types of interactive whiteboards:

- Infrared interactive whiteboards

- Resistive touch interactive whiteboards

- Electromagnetic boards with a pen

- IR-pen based ultrasonic interactive whiteboards

- Virtual interactive whiteboards using a projector

- Interactive screen

\section{Learning materials for use on interactive whiteboards}

The preparation of quality and imaginative materials requires a lot of time and knowledge. We believe that this finding is one of the most common reasons for not taking advantage of all the benefits of the interactive whiteboard and the related equipment. The benefit of using an interactive whiteboard in teaching is that it triggers the students' thought processes, thus facilitating the cognitive process. (Lotrič Komac, 2011).

A survey on the impact of the use of the interactive whiteboard and teaching materials among teachers in the Republic of Serbia (Oprea, 2017) highlighted among the advantages a higher quality of instruction (57\%) and an easier achievement of the lesson goals. A higher level of student motivation is found by $69 \%$ of teachers, while more than a half (52\%) observed the influence of the interactive whiteboard on students' participation during lessons.

By using the interactive whiteboard students become more alert, more motivated, and active in all phases of the lesson. The use of the interactive whiteboard in the classroom provides greater clarity in the interpretation of various phenomena, whereby students process the knowledge. With the didactically designed use of the interactive whiteboard and by solving i-slides, the students build knowledge independently. The teacher can use the interactive whiteboard and didactically design it in all phases of instruction: verification of the prior knowledge, motivation, introduction, and consolidation of subject matter, examination, and assessment (Baloh \& Burger Muhič, 2011).

Oprea (2017), in a review of the practice in the Republic of Serbia, points out that teachers recognize the possibilities of using an interactive whiteboard to show lesson structure, visualize connections and relationships, simulation and animation, present students' works and summaries of content.

\section{Interactive whiteboard software}

The accompanying software enables the use of various didactic resources such as i-slides, eslides, didactic games, web applications, online learning environments, etc. Therefore, interactive whiteboards can be used at all levels of education and in all subjects. At the same time, the interactive whiteboard software enables others to learn collaboratively, students to co-create content, provide tools to test knowledge with smart devices and computers, gamification, i.e., learning through games, etc. (Collaboration Software \& Displays - SMART Technologies, 2018). A 2016 survey found that learning through games brings $66 \%$ greater learning success. However, we must not neglect the fact that success is not only demonstrated by the use of technology and software, but a combination of good teaching practices, software, and hardware is important for success (Education SMART Technologies, 2018).

\section{Interactivity with the use of ICT in education}

Interactivity means investing on both sides, fair exchange, cooperation where both parties gain something (Sambolić Beganović, Vičič Krabonja, \& Šavli, 2011). However, any teaching material provided online or with the help of ICT is not necessarily interactive. It is a misconception that the use of ICT automatically means interactivity. It is nec- 
essary to be aware that pointless and reckless use of technology can negatively affect the links between short-term and long-term memory. The use of ICT in teaching also includes the use of interactive whiteboards and related software. Therefore, the results of the research that only $24 \%$ of teachers are well familiar with the associated interactive whiteboard software and the remaining $76 \%$ are only partially familiar, are worrying. From this, we can conclude that a part of these teachers uses the interactive whiteboard only for display (Adanič, 2018).

For this reason, interactive whiteboard and software manufacturers want to approach this type of teacher by simplifying the software and adding different pre-made interactive learning content. Teachers can adapt these to their needs without needing more sophisticated knowledge. At the same time, they have available examples that can later be further developed with a little more knowledge and effort.

The use of interactive boards and complementary teaching materials support an important didactic strategy of the game, i.e., the introduction of gamification into the learning process. Namely, games enable the transfer of knowledge and its application in certain circumstances and help the gradual transformation of concrete operations into their internalization, i.e., the thought process. Knowledge gained through such games is productive and contrary to passive knowledge of facts and rules (Gerlič, 2000).

\section{Gamification}

Didactic games are closely related to the concept of gamification. Nowadays, companies also use gamification like applications to attract customers' interest in their products. Even the thought of a game increases a person's motivation to work. Gamification has also appeared in educational institutions as a means of motivating students. While playing didactic games, students are entertained and rewarded with knowledge and skills (Brian J., 2014).
"Gamification" is a way of thinking that implies a basic game design and logic in developing and implementing already established learning or action processes (Blanc, 2018). Through games, we encourage motivation and encourage "players" to participate and learn at the same time, which is also called collaborative learning.

\section{Teaching fine arts through games}

In terms of teaching, the field of fine arts offers a wide range of teaching content where a gamebased approach can be a part of the teaching process.

The game in the visual arts is one of the learning activities and represents one of the links between understanding the visual language and the expression of the visual arts. It allows students to combine knowledge and new ideas in a relaxed way (Tacol, 2003). The teacher can use the game at all stages of the learning process according to the design of the art task. With the game, the teacher has the opportunity to enable learning and understanding of the subject matter, so that students can develop manual skills and enrich their artistic imagination and visual memory. The activity of the game must be dynamic, effective, diverse, emotionally colored, unrepeatable, process-oriented, not result-oriented, since students are not aware of the end goal, so they must be the motive and the goal of the game (Adanič, 2018).

\section{Examples of didactical interactive whiteboard games}

Below we will present selected examples of didactic games for teaching fine arts in Slovenia and physics in the Republic of Serbia. The examples are made using the SMART Notebook software, which is part of the SMART Learning Suite software scheme, which is adapted to the interactive boards of this manufacturer. Interactive boards of other manufacturers have software adapted to their products, and therefore, the learning contents are not transferable. 
Fine arts teachers can use didactic games at all stages of the learning process in the ninth grade of primary school. The games we have designed are in line with the Ninth Grade Art Curriculum and can be a tool for introductory motivation, repetition before testing, consolidation of the subject matter, repetition before national proficiency tests, etc.

Study materials on the SMART Exchange website are limited to the English language and do not cover the aims of the curriculum for the fine arts of the Republic of Slovenia. Therefore, as part of a national project to increase the adoption and use of interactive content on smart devices, we wanted to build an online portal where literature and information on interactive content would be available. In doing so, we wanted to ensure the sharing and the co-use of interactive content of Slovenian elementary and secondary school teachers. The presented collection of materials for fine arts - products is the work of Larisa Adanic, a student at the Faculty of Education in Maribor and published on the portal i - Steljes (i - Steljes, 2017). The selected examples are presented in the following chapters.

\section{The teaching of fine arts - Slovenia}

\section{Didactic game - Crossword}

In general, a crossword puzzle is a puzzle where words are written in horizontal and vertical lines (ISJ ZRC SAZU: Slovar slovenskega knjižnega jezika (Dictionary of Slovenian Literary Language, op. p.), 2018). In the design, we used the classic game of Crossword by designing it so that a participant immediately receives a response about the suitability of the letter entered.

The letters are to be inserted into the crossword by dragging them from the list of letters shown on the left side of the material, as shown in Figure 9. If the selected letter is appropriate, the frame pulls it in itself; otherwise, it rejects it and returns it to the letter list. When all the words in the crossword have been sorted out correctly, the main word of the crossword is displayed. The main word of the cross- word puzzle is to obtain by writing the corresponding letters from the marked, numbered boxes. Individual words are to be chosen out from the teaching content of the subject of fine arts that the students had already acquired. For the main words, we used the keywords of the learning content, which students will learn about in the continuation of the learning unit. In this way, art teachers can use the game as an introductory motivation for learning a new subject matter.

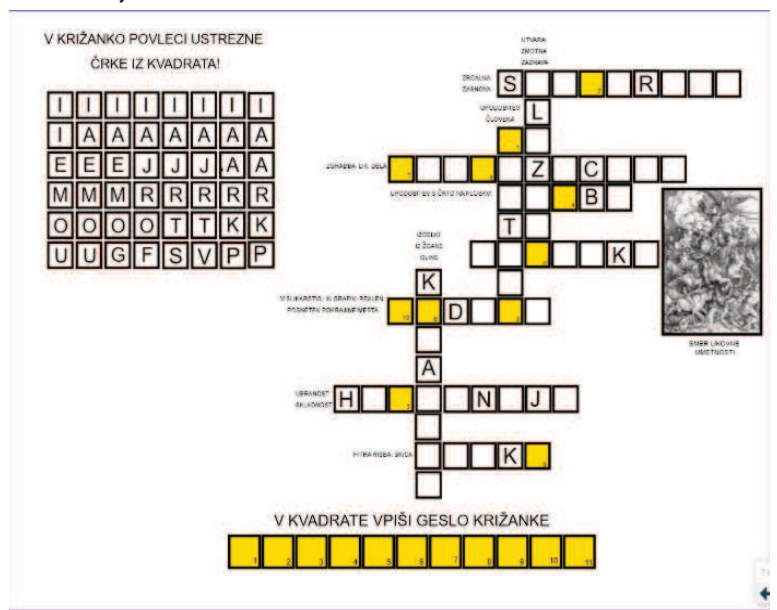

Figure 1: Image of the didactic game - Crossword

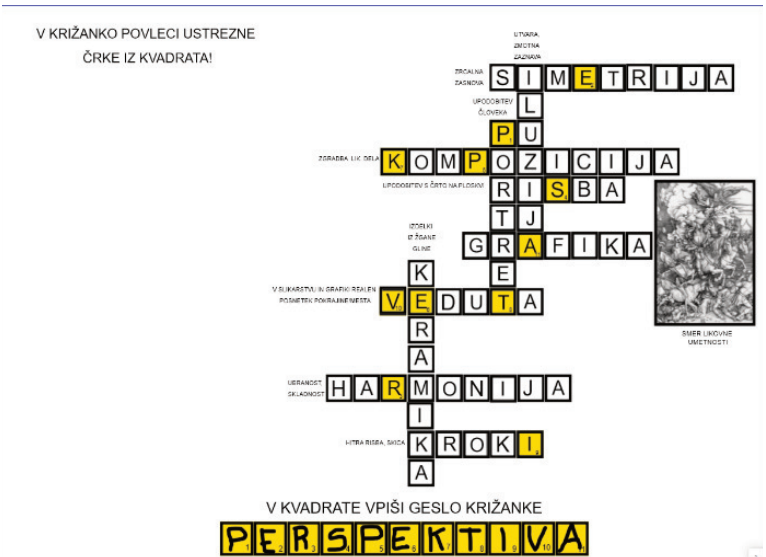

Figure 2: Image of the solved didactic game-Crossword 148 


\section{Didactic game - Image revealing}

For playing the game, it is necessary to split into two groups before starting with the help of the widget mentioned above. The game begins when the first group chooses the square number of the image it wants to reveal. Each square consists of several layers: the square number, the question, the answer, and the reproduction part. When a question appears which students try to answer, the teacher checks the correctness of the answer by removing the layer of the field where the appropriate answer appears. If the students answer correctly, the teacher removes the penultimate layer to reveal a part of the image. The groups play alternately. The group that first reveals three boxes has the opportunity to reveal the whole picture by naming it. The group which first identifies which image is in the background is the winner.



Figure 3: Didactic game of Image revealing when played

We have adapted the background photos and questions to a specific learning topic. In the case presented, the background is the Mona Lisa painting by the Renaissance artist Leonardo da Vinci, where an aerial perspective emerges in the background, which is the theme of the following part of the lesson. Such an approach allows the teacher to discuss the picture at the end of the game with the students and link the topic of the conversation to new teaching material.

\section{Didactic game - the Maze}

To play the game, you need to turn on dualscreen mode before starting, which means that one slide is on the left side and the other on the right side of the screen.

The maze game is played in two arbitrary groups. The teacher sets the starting group by using virtual dice. The group, in turn, selects the field number in which the question is hidden. If the group answers the question correctly, it has the opportunity to roll the dice. The group can move around the maze by the number of fields indicated by the dice. The teams alternately roll the dice and answer questions. The group that first manages to get to the other side of the maze is the winner of the game. If the teacher does not have enough time to complete the whole game, he or she can place the groups' figures in the middle of the maze. The winning group is the one who first finds the way out of the maze.

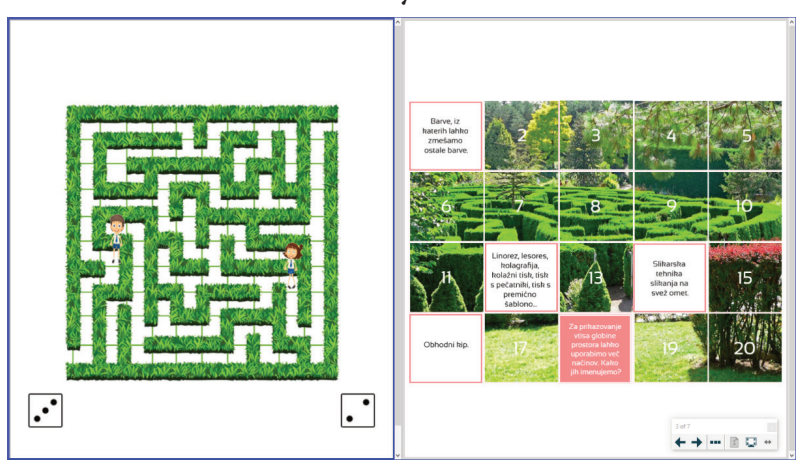

Figure 4: Didactic game - the Maze

\section{Didactic game - Sorting}

We created the game using an activity template called "Match 'Em up!". Like the Memory game, this game has the same accessories (random picker, button, and timer). The words and phrases in the left column should be properly linked to the images in the right column, as shown. Since the images are small in size, we have added a gallery with larger reproductions and the associated data. 


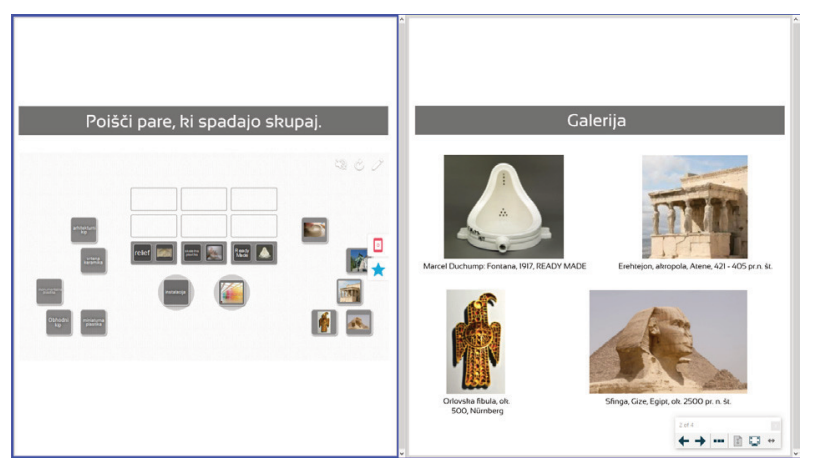

Figure 5: Didactic game - Sorting

\section{Physics teaching - Serbia}

The didactic games repository for interactive whiteboards in the Republic of Serbia is not currently available. Therefore, didactic interactive board games are created by individuals on their initiative, which confirms the findings of the research (Ristić, 2018) in the Republic of Serbia that the production of such materials is commonly based on the enthusiasm of individuals.

Such examples are summarized by Ivana Oprea (2017) and designed by a physics teacher to make the teaching content of physics lessons more interesting to students, make problems easier to understand, and to stimulate memory through the use of animation. The author of the didactic games highlights the interactive whiteboard as a very useful teaching tool, especially for tasks that require precise physical constructions, such as geometric optics.

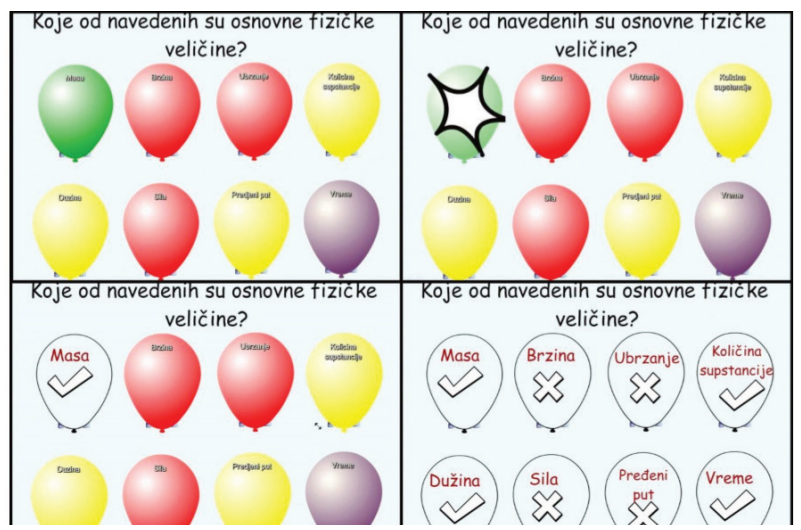

Figure 6: Didactic game - Basic physical quantities
On the screen, we see balloons of different colors with some text on them. In this case, these are physical quantities, and we are required to extract the basic physical quantities. We need to click on the balloon with the basic physical quantity. At the moment we click on the balloon, it bursts, and it detects if this is the correct answer. The sound accompanies the picture, so we believe this is interesting for children because we all like to play with balloons. Through this game, children can memorize basic physical quantity names without learning them by heart. In this picture, there are not all seven basic physical quantities, but only four, just because we think they should learn gradually. In the Smart Notebook software within this game on the following pages we can add, for example, one new basic physical quantity on each page, repeat with mixed balloons, and thus reach the end where all the basic physical quantities will appear on the screen, and then the children will already be able to distinguish the basic ones. This game is good because it does not take much time, students can stand in front of the board and compete for more correct answers, etc.

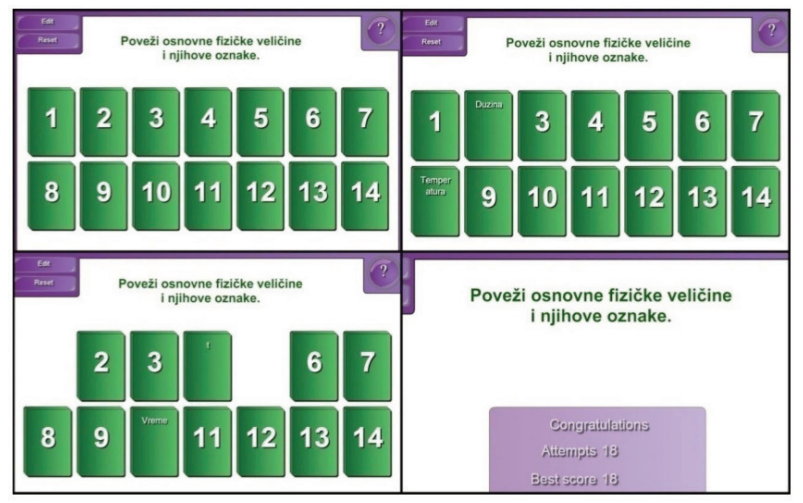

Figure 7: Didactic game - Physical quantities and symbols

There are 14 cards on the board. Above them is the instruction that we have to match the basic physical quantities and their symbols. Therefore, we are not looking for two of the same cards, but when we open a card, and for example, if it says length, we 
look for the appropriate symbol on it, and the symbol for length is "l". By opening the cards, we look for the symbol 1 and, at the same time, remember what we have opened, because we need six more basic physical quantities to match with their symbols. When we match a quantity and its symbol, these two cards disappear from the screen and so on. This game can also be played in the way that one student plays, and the final number of his attempts is displayed, followed by the next player, and the winner is the one who removed all the cards in fewer attempts. Or, it can be played as we used to play a memory game in childhood. It is one student's turn as long as he or she manages to match pairs; when he or she makes a mistake, it is the next student's turn. The results of how many pairs each student has matched are recorded on the board. The winner is the one who has the most pairs. There are many ways for children to be entertained and yet to learn something. In this game, students practice memory, but also discover what the basic physical quantities are, match them with their symbols, learn and determine which symbols are for the basic physical quantities.

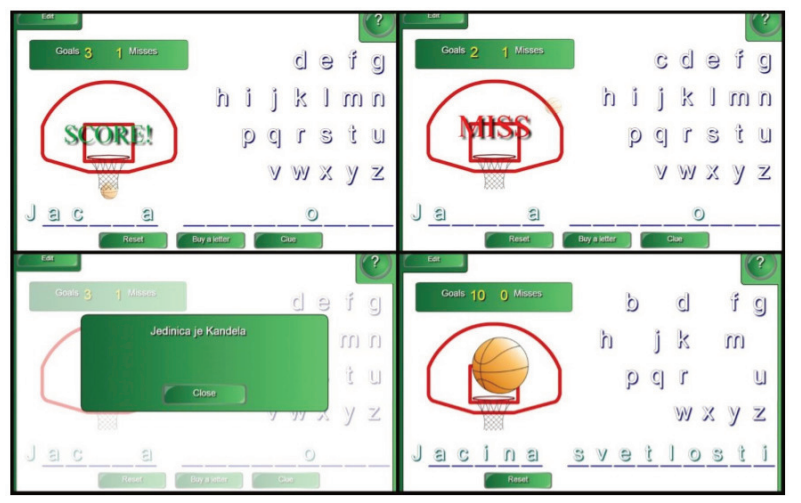

Figure 8: Didactic game - assembling words

This game is similar to the hangman game. We guess the letters and assemble the word. In this case, the game proposes the word which we can see in the basket picture. When we click on a letter that is in the word, it is written down, and the ball hits the basket, and we score. If we click on a letter that is not part of the word, we miss the basket. There is another option if we cannot guess which is that a little help appears. In this case, a window appears that says, "The unit is candela." If we have mastered basic physical quantities and units, we will know the solution immediately. One student or two can participate in this game. Again, as in the previous games, we can alternately or individually compete by counting attempts in the end, and the winner is the one who has solved the required term with the least number of attempts.

\section{Methodology}

\section{Purpose}

The use of didactic games was tested in art classes in the 9th grade at one of the primary schools (Adanič, 2018). After playing the games, we distributed questionnaires to the students to get some feedback regarding their use. We wanted to know:

- what attracted students to the use of didactic games.

- what they remembered best

- why they remembered the elements best

\section{Data processing procedures}

The data obtained by the questionnaire were analyzed using the statistical method of frequency distributions. The analysis of interviews is shown in the form of category ranks.

\section{Results}

\section{Elements that attract students}

After the lesson, we were first interested in what attracted the students most to using didactic games on the interactive whiteboard. 
Table 1: The elements that students were most interested in

\begin{tabular}{|l|c|}
\hline Elements & $\mathrm{f}$ \\
\hline Game & 37 \\
\hline A new way of teaching & 8 \\
\hline Group competition & 3 \\
\hline
\end{tabular}

The most frequent responses of students in the ninth grade of both primary schools were related to the type of game, so they wrote down the title of the game that attracted them the most. The following were answers related to a new way of teaching and competing in groups. The students also emphasized the unpredictable feelings they felt with the didactic Quiz game, which contains a wheel of fortune. Among other things, they wrote that they liked discovering something new in a fun way and also learning something. We related this student response to Murphy's laws of game learning. In playing, they were encouraged by points that allowed them to advance and win over the opposing group (Murphy, 2012). Based on these findings, we can answer the research question, where we were interested in what attracted the students the most to the use of didactic games.

\section{Elements that students memorize}

The purpose of using didactic games is, among other things, to improve memory. We were interested to find out what the students remembered the most after using the didactic games on the interactive whiteboard.

Table 2: Elements that students remembered the most

\begin{tabular}{|l|c|}
\hline Categories & $\mathrm{f}$ \\
\hline Type/title of the game & 21 \\
\hline Subject matter & 12 \\
\hline Structure of the game & 10 \\
\hline
\end{tabular}

In their answers, most students indicated the type or title of the didactic game. For the most part, students cited games that contained a competitive model. In the second place, the students mentioned the concepts of the subject matter they learned in the context of didactic games. In the third place was the game structure where students listed either reproduction of artworks that were part of the didactic games, or elements of the game such as a timer, a wheel of fortune, and a random student selector. We want to emphasize an interesting answer where the student answered that he or she most remembered the way of thinking in a particular game. The outcome points to the fact that learning or remembering is more effective when positive emotions and feelings are present in the cognitive process (Chai, Hafeez, Saad, \& Aamir, 2017). They also gained an intense experience through playing, which arose through commitment and immersion in competitive games (Murphy, 2012).

\section{Why students memorize elements}

Didactic games transmit a series of stimuli that affect the memory process. Regarding the matter that students remembered the most, we were interested in why students remembered certain elements.

\section{Table 3: Reasons for students remembering the} elements

\begin{tabular}{|l|c|}
\hline Categories & $\mathrm{f}$ \\
\hline $\begin{array}{l}\text { Interesting, instructive, and } \\
\text { entertaining. }\end{array}$ & 24 \\
\hline $\begin{array}{l}\text { Attractiveness, structure, and } \\
\text { presentation of the game. }\end{array}$ & 8 \\
\hline Competing and triumphing. & 4 \\
\hline
\end{tabular}

In their answers, most of the students emphasized the fact that they remembered the subject matter, structure, and type of games the most because the games were interesting, instructive, and fun. Next come attractiveness, structure, and presentation of didactic games, which are somewhat relat- 
ed to the first category. As of the last, students again indicated competition and triumph. Some students also emphasized causes such as a new way of teaching, learning from mistakes, the size of projection, already acquired knowledge, an interesting concept, etc.

\section{Conclusion}

In the Republic of Slovenia, the use of interactive whiteboards is present and widespread, while in the Republic of Serbia, the use depends very much on the current economic circumstances. The situation in the Republic of Serbia is somewhat better in larger cities. It is crucial for both countries that the mere presence of interactive whiteboards does not mean that teachers often use them. This situation can be attributed with great certainty to the lack of didactic materials suitable for use on interactive whiteboards. The lack is related to the language barrier since the existing materials for the specific interactive whiteboards are mostly in a foreign language. They are also tailored to the specificities of individual school systems and are often incompatible with local curricula. Another reason is the incompatibility of the tools for the production of didactic content, which is product-oriented and non-transferable. An important reason for the limited use is the lack of knowledge of the tools for the development and preparation of didactic content. In trying to avoid these obstacles, we have created examples of didactic content suitable for interactive whiteboards in the field of teaching fine arts in elementary school. Based on the experience, we would then build a repository of didactic materials for teachers to use in their work. We tested didactic games in elementary school and found that students wanted to use the interactive whiteboard and didactic games from the collection. The games were rated by the students as interesting, entertaining, and instructive, and at the same time, they felt that they were motivated to continue their work by integrating competitiveness and team spirit. We think that made-up didactic games have the potential to motivate students. As the responses to the presented collection of didactic games were positive, there are reasons to supplement the collection in the future with content for teaching fine arts for all ages and to implement the collection in art-pedagogical practice. We will conclude with the thought that technology cannot replace or substitute a teacher. It is the teacher who adds value to technology and not vice versa.

\section{References:}

- Adanič, L. (2018). Didaktične razsežnosti interaktivne table pri pouku likovne umetnosti v 9. razredu osnovne šole v Sloveniji. Univerza v Mariboru, Pedagoška fakulteta. Retrieved March 28, 2019 from https:// dk.um.si/IzpisGradiva.php?lang=slv\&id=70908

- Baloh, E., \& Burger Muhič, A. (2011). Didaktični potencial i-tabel . BILTEN: I-naprave in in pouk, 11-14.

- Bhowmik, A. (2014). Interactive Displays: Natural Human-Interface Technologies. Wiley.

- Blanc, B. (20. 3 2018). Aktualno 2.0. From "Igrafikacija" - novo strokovno orodje?: http://www.aktualno. biz/2014/01/igrafikacija-novo-strokovno-orodje.html

- Brian J., A. (2014). Gamification in Education. Proceedings of ASBBS 21(1), 32-39.

- Bučar, U. (2011). Koliko i-tabel že imamo in uporabljamo? Bilten E-šolstva, 9-10.

- Chai, T. M., Hafeez, A. U., Saad, M. N., \& Aamir, M. S. (2017). The Influences of Emotion on Learning and Memory. Frontiers in Psychology, 14-54. doi:10.3389/fpsyg.2017.01454 
- Collaboration Software \& Displays - SMART Technologies. (14. 3 2018). Retrieved April 10, 2019 from Downloads - User's Guide: http://downloads.smarttech.com/media/sitecore/en/support/product/ sbfpd/7000series/guides/sbid7000userguide_18jul17.pdf

- Džigurski, S., Marković, S., \& Šćepanović, D. (2013). Istraživanje o upotrebi informaciono-komunikacionih tehnologija u školama u Srbiji. Beograd: Tim za socialno uključivanje i smanjenej siromaštva. Retrieved May 18, 2019 from http://socijalnoukljucivanje.gov.rs/wp-content/uploads/2014/06/Istrazivanje-o-upotrebiIKT-u-skolama-u-Srbiji-jun-2013.pdf

- Education SMART Technologies. (25. 5 2018). Retrieved April 10, 2019 from Teaching, technology and learning: Understanding the interconnection: https://education.smarttech.com/ /media/files/events\%20 and\%20tradeshows/ed_teachingtechnologylearning_06222016.ashx

- Gerlič, I. (2000). Sodobna informacijska tehnologija v izobraževanju. Ljubljana: Državna založba Slovenije.

- $i$-Steljes. (7. 8 2017). Retrieved May 17, 2019 from Portal interaktivnih vsebin: www.i-steljes.eu

- Lotrič Komac, T. (2011). Gradiva pripravljan za učence in ne zase. Bilten: I-naprave in i-pouk, 10-11.

- Murphy, C. (2012). Why Games Work and the Science of Learning. Selected Papers Presented at MODSIM World 2011 Conference and Expo (383-392). Virginia Beach: Langley Research Center . Retrieved March 29, 2018 from Why Games Work and the Science of Learning: https://pdfs.semanticscholar.org/1917/135650c9 e5ba2d92216b8d9df87e21df5fb5.pdf

- Oprea, I. (2017). Upotreba interaktivne table i njena zastupljenost (master rad). Novi sad: Univerzitet u Novom Sadu, Prirodno matematički fakultet. Retrieved April 20, 2019 from http://www.df.uns.ac.rs/files/200/ivana_ oprea_-_master_rad_(f1-244).pdf

- Ristić, M. (2018). Digital competencies of teachers and associates. V V. Katić (Ured.), XXIV Skup “Trendovi razvoja: Digitalizacija visokog obrazovanja" (pp. 1-4). Kopaonik: Fakultet tehničkih nauka Univerziteta u Novom Sadu.

- Sambolić Beganović, A., Vičič Krabonja, M., \& Šavli, V. (6 2011). Ali je interaktiven pouk zares nujna tehnologija? Bilten E-šolstva, 5-6.

- Tacol, T. (2003). Likovno izražanje. Didaktična izhodišča za problemski pouk likovne vzgoje v devetletni osnovni šoli. Ljubljana: Debora.

- Vukanac, D. (2014). Uporaba interaktivne table učiteljev razrednega pouka v Sloveniji. Retrieved April 20, 2019 from https://share.upr.si/PEF/EDIPLOME/DIPLOMSKA_DELA/Vukanac_Dasa_2014.pdf 


\title{
Томаж Ф. Братина
}

Универзитет у Марибору, Педагошки факултет, Марибор, Република Словенија

\author{
Лариса 3. Аданич \\ Inovatio d.o.o, Марибор, Република Словенија
}

\section{Предраг Б. Пртљага}

Висока школа струковних студија за образовање васпитача, Вршац, Република Србија

\section{НАСТАВНИЦИ, ИНТЕРАКТИВНЕ ТАБЛЕ И МАТЕРИЈАЛИ ЗА УЧЕЊЕ У СЛОВЕНИЈИ И СРБИЈИ}


софйвер. Коришћене свих йреgностии које иружају иниеракииивне йабле честио је оірани-

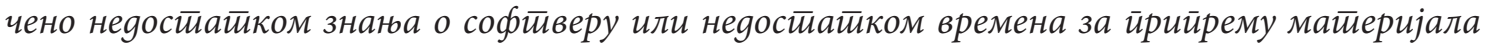
за учеюе. Постиојећи иракитични ирреgлози, иримери или ияеје о йоме како иррииремитии нас-



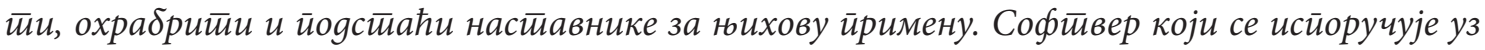

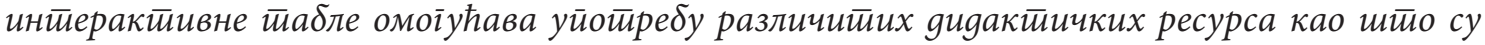
и-слајgови, е-слајдови, gияакииччке иіре, веб-айликације, окружења за учење на мрежи ийg.

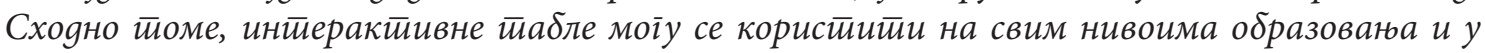

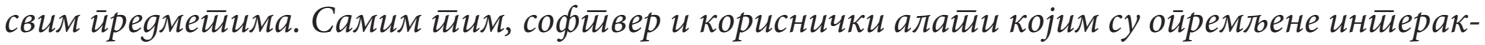

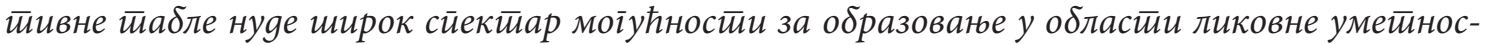
$\bar{и} и$. Настиавни саяржаји засновани на иіри у визуелним уметиностимма јеgна су оg реgовних

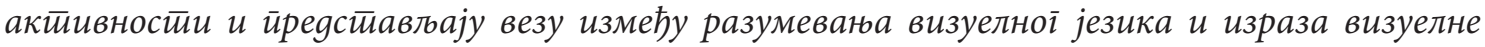
уметиностии. Настиавник може gа користии иіру у свим фазама йроцеса учењь, у склаgу са gизајном настиавноі̄ или уметиничкоі заgайка. Примери навеgени у овом раgу указују на йреg-



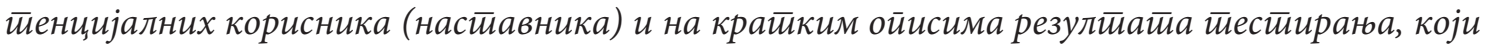

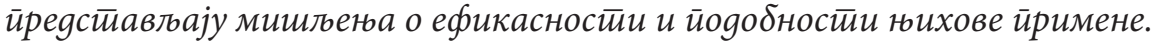



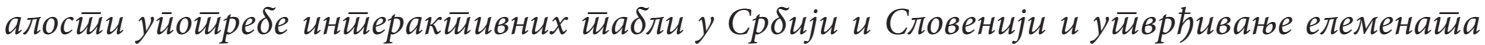


йостиојань оgіоварајућих насииавних саяржаја.



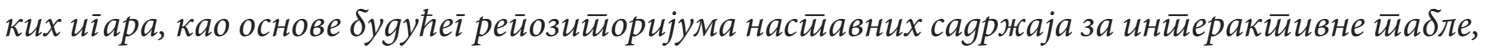

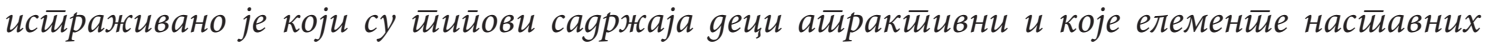
саяржаја усвајају у већој мери. Након шито су иірали иіре које омоїућују учене и разумеване

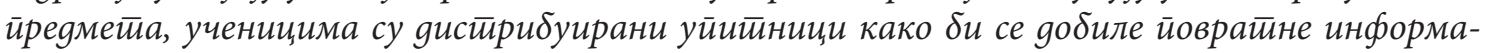

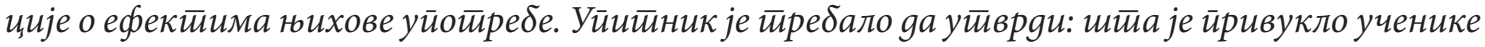

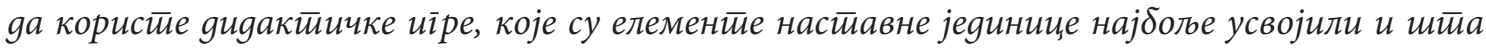




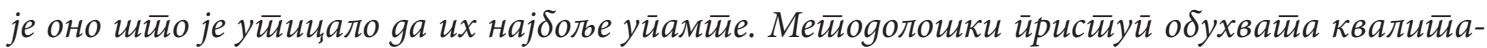

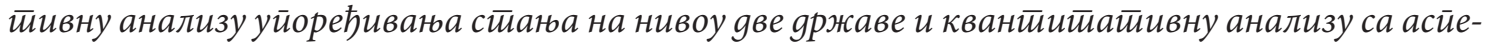

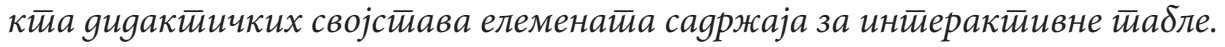

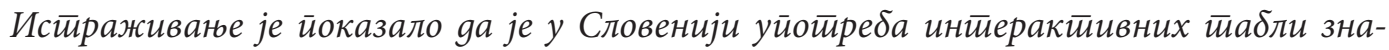

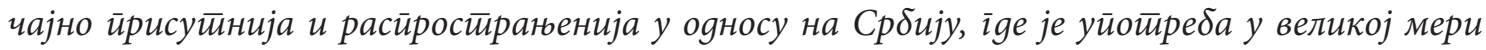

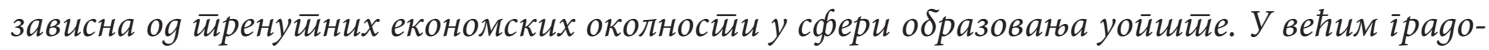
вима у Србији је ситиуација нешйо бола, али је за обе земље уйврђено яа само йрисустиво

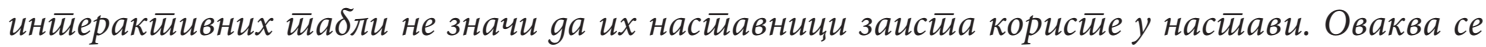

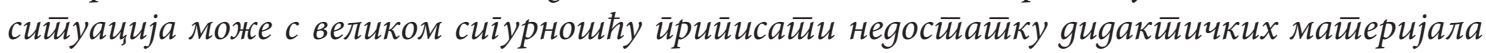





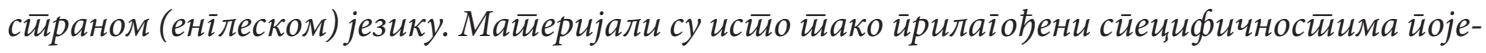
gиних школских систиема и честио су несйојиви са локалним настиавним ироіррамима. Клучни





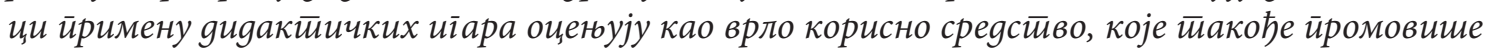


занимливе, забавне и йоучне, а истиовремено су осећали gа су мойивисани gа настияве са

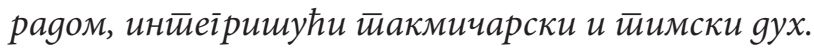

Коначно, уйврђена је и нужности иррииреме рейозийоријума саяржаја који мора битии


ном йристиуйу уз йошйоване унайреg gефинисаних ауйорских йрава.

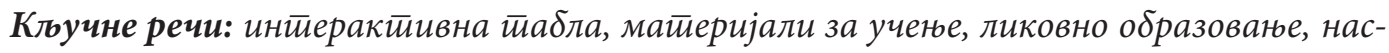

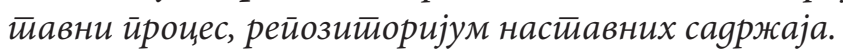

